\title{
Vector Competence of Culex quinquefasciatus Say from Different Regions of Brazil to Dirofilaria immitis
}

\author{
Silvia Maria Mendes Ahid/+, Pádua Suely da Silva Vasconcelos, \\ Ricardo Lourenço-de-Oliveira*
}

Departamento de Patologia, Curso de Medicina Veterinária, Universidade Estadual do Maranhão, Campus Paulo VI, Tirirical, 65054-970 São Luís, MA, Brasil *Laboratório de Transmissores de Hematozoários, Departamento de Entomologia, Instituto Oswaldo Cruz, Rio de Janeiro, RJ, Brasil

The vector competence of Culex quinquefasciatus from five localities in Brazil to Dirofilaria immitis was evaluated experimentally. Females from each locality were fed on an infected dog $(\sim 6$ microfilariae/ $\mu$ l blood). A sample of blood fed mosquitoes were dissected approximately $1 \mathrm{~h}$ after blood meal. These results demonstrated that all had ingested microfilariae (mean, 4.8 to 24.6 microfilariae/mosquito). Fifteen days after the infected blood meal, the infection and infective rates were low in all populations of Cx. quinquefasciatus. The mean number of infective larvae detected in the head and proboscis of these mosquitoes was 1-1.5. The vector efficiency, the number of microfilariae ingested/ number of infective larvae, was low for all populations of $\mathrm{Cx}$. quinquefasciatus. However, the survival rate for all populations was high (range 50-75\%). The survival rate of Aedes aegypti assayed simultaneously for comparison was low (24.7\%), while the vector efficiency was much higher than for Cx. quinquefasciatus. These data suggest that the vector competence of all assayed populations of $\mathrm{Cx}$. quinquefasciatus to D. immitis in Brazil is similar and that this species is a secondary vector due to its low susceptibility. Nevertheless, vector capacity may vary between populations due to differences in biting frequency on dogs that has been reported in Brazil.

Keys words: Dirofilaria immitis - Culex quinquefasciatus - mosquito - vector competence - Culicidae - Brazil

Dirofilaria immitis (Leidy) is a nematode parasite that infects the right ventricle and pulmonary artery of dogs and other carnivores, and is transmitted by mosquitoes (Diptera, Culicidae). The parasite has a wide geographical distribution, with dogs serving as the principle host, although infection has been reported in other animals and occasionally in man (Robinson et al. 1977, Kasai et al. 1981). The complete development of microfilariae has been reported in species of Culex, Aedes, Anopheles, Mansonia, Psorophora and Coquillettidia (Ludlam et al. 1970).

In some insects there exist biochemical products in the hemolymph and other tissues, including the Malpighian tubule cells and thoracic muscle cells, that may block the development of the parasite by mechanisms comprising sequestration, encapsulation and melanization. The intensity of these reactions varies according to the susceptibility of the mosquito host, resulting in high survival rates

\footnotetext{
${ }^{+}$Corresponding author. Fax: 55-98-245.1500. E-mail: silviaahid@bol.com.br

Received 2 December 1999

Accepted 19 June 2000
}

of both the parasite and mosquitoes of susceptible populations (Christensen 1981, Christensen \& Tracy 1989, Talluri \& Cancrini 1994). The migration and development of large numbers of $D$. immitis larvae within the mosquito can produce elevated levels of host mortality (Nayar \& Sauerman 1975). Thus, melanization can act as an important mechanism for vector survival by limiting the number of larvae that complete development and thereby guaranteeing its own survival (Christensen 1981, Christensen \& Forton 1986, Christensen \& Tracy 1989). In addition, some mosquito species have well developed cibarial armature, the teeth of which, when numerous and/or developed, injuring ingested microfilariae and reducing their survival potential (McGreevy et al. 1978, Coluzzi et al. 1982).

The importance of $C x$. quinquefasciatus Say as an intermediate host for Wuchereria bancrofti is well known. In 1901, Bancroft had already noted the development of $D$. immitis in $C x$. pipiens fatigans ( $=C x$. quinquefasciatus) (apud Villavaso $\&$ Steelman 1970). The vector competence of nocturnal domestic mosquitoes ( $C x$. quinquefasciatus and $C x$. pipiens and their subspecies) has been discussed by various researchers worldwide demonstrating the various levels of susceptibility to infection according to geographical location (Ludlam 
et al. 1970, Lowrie 1991, Loftin et al. 1995). In Rio de Janeiro $C x$. quinquefasciatus was considered a secondary vector of $D$. immitis (Labarthe et al. 1998a, b). In São Luís (State of Maranhão), where the prevalence of canine dirofilariasis varies from 11.3 to $52.5 \%$ depending on the origin of the dogs and the proximity to the sea shore, only $0.5 \%$ of the Ae. taeniorhynchus and $0.1 \%$ of $C x$. quinquefasciatus examined were found to be naturally infected. $C x$. quinquefasciatus accounted for $54 \%$ of the total mosquitoes collected (man and dogs) and $96.7 \%$ of the total captured in dog baited traps (Ahid et al. 1999, Ahid \& Lourenço-deOliveira 1999). The marked difference noted in the frequency of $C x$. quinquefasciatus collection using live dog baited traps in Maranhão and that seen in Rio de Janeiro could reflect differences in the vector capacity of this species in these two locations. Moreover, there have been reports of vector competence differences between $C x$. quinquefasciatus populations isolated from regions with various levels of prevalence of bancroftian filariasis (Janousek \& Lowrie 1989, Lowrie et al 1989, Brito et al. 1997, Calheiros et al. 1998). Could $C x$. quinquefasciatus from Maranhão show a different degree of susceptibility to infection with $D$. immitis in comparison to other parts of Brazil?

In the present study, the vector competence of $C x$. quinquefasciatus in relation to $D$. immitis was evaluated under laboratory conditions using mosquitoes originating from five distinct Brazilian populations.

\section{MATERIALS AND METHODS}

The experiments were performed using female Cx. quinquefasciatus derived from 32 to 107 wild collected females from each of five test locations: Recife, Pernambuco (PE), the city of Rio de Janeiro (RJ), Porto Velho, Rondônia (RO), São Luís, Maranhão (MA), and Florianópolis, Santa Catarina (SC). Transmission of D. immitis was previously reported in all sample locations (Alves et al. 1993, Labarthe 1997, Ahid et al. 1999), except Porto Velho, where the examination of 45 dogs for the presence of the parasite were negative (Lima et al. 1996). The progenies from each location were reared separately, but simultaneously under the same conditions with regard to feeding, temperature and illumination. Larvae were reared in groups of approximately 400 in $40 \times 25 \mathrm{~cm}$ pans and provided with fish food (TetraMin ${ }^{\mathrm{Tm}}$ ) mixed with cat food (Whiskas ${ }^{T m}$ ). Pupae were transferred daily (in containers filled with tap water) to screened cages $(40 \times 40 \times 40 \mathrm{~cm})$ where adults emerged. Adult mosquitoes were daily provided with $10 \%$ sucrose solution. Three to five days-old nuliparous $\left(\mathrm{F}_{7}\right)$ females were used for experimental infections with $D$. immitis. Twenty-four hours prior to bloodfeeding on the infected blood source, sucrose was removed. The colonies were maintained and experimental infections were conducted in the laboratory at $29^{\circ} \mathrm{C} \pm 1{ }^{\circ} \mathrm{C}$ and $70 \% \pm 10 \%$ relative humidity $(\mathrm{RH})$

To identify different mosquito populations following feeding, the females from each location were marked with luminous powder of different colors (Luminous Powder-Bioquip products) a few minutes prior to the infection experiment. Females were separated by observing the color of adhering luminous powder when illuminated with a black fluorescent light source. Approximately 1,500 female $C x$. quinquefasciatus (approximately 300 from each population) and 300 Ae. aegypti (São Luís strain, as control) reared under the same conditions as $C x$. quinquefasciatus, were placed simultaneously in a covered cage $(120 \times 100 \times 80 \mathrm{~cm})$ along with a previously anesthetized, infected dog. All the mosquitoes were allowed to feed on the dog from $23.00 \mathrm{~h}$ to $3.00 \mathrm{~h}$ in total darkness. During the first hour of exposure to the dog five engorged females from each population were collected using an aspirator and immediately dissected (as described below) to determine the number of ingested microfilariae.

A nine years old, male Labrador with a natural D. immitis infection (approximately six microfilariae per $\mu$ l of blood) was used as the source of infection for the test mosquitoes. The dog was anaesthetized with acepramazine $(0.2 \mathrm{ml} / \mathrm{kg})$ during the entire exposure period. To determine the average number of circulating microfilariae, six $20 \mu \mathrm{l}$ blood samples were collected from the dog and examined by Giemsa staining. Three of the samples were collected $24 \mathrm{~h}$ prior to exposure to the mosquitoes while the other three were collected $1 \mathrm{~h}$ pre-exposure.

At the end of the $4 \mathrm{~h}$ exposure period, engorged females from each population were collected and transferred to a screened circular cage $(8 \mathrm{~cm}$ diameter), held in an incubator at $28^{\circ} \mathrm{C} \pm 1{ }^{\circ} \mathrm{C}$ and $70 \%(\mathrm{RH})$ and provided with $10 \%$ sucrose. Partially engorged females were excluded from the experiment. Moribund females were removed and dissected daily to determine the progress of the infection. At 15 days post infection all surviving females were anaesthetized in ethyl acetate vapor, their wings and legs removed, and then dissected in sterile saline $(0.89 \% \mathrm{NaCl})$. The head, thorax, stomach and Malpighian tubules were dissected with the help of needles and examined individually for the presence of larval forms (Lourenço-de Oliveira \& Deane 1995). The larvae encountered were classified on the basis of their larval development stage as described by Taylor (1960). 
In this study we refer to "infected mosquitoes" as those in which larvae of $D$. immitis were observed at any stage of development. The term "infective mosquitoes" refers to mosquitoes that had third stage larvae in their head and/or proboscis $(\mathrm{H} / \mathrm{p})$. The analysis of the average number of microfilariae ingested soon after engorgement was performed using the Duncan test in order to transform the data into a logarithmic form for analysis of variance at the $5 \%$ level. Other variables were analyzed using the $\chi^{2}$ test for non parametric data at the $5 \%$ level.

\section{RESULTS AND DISCUSSION}

Among the total female $C x$. quinquefasciatus (approximately 300 per population) placed in contact with the infected dog, 858 engorged. A variable percentage of engorged females was observed, ranging from 40 to $98 \%$ for different populations (Table I). In the case of Ae. aegypti 57\% of the females engorged. All Cx. quinquefasciatus dissected immediately after feeding contained microfilariae in the midgut, with rates that varied from 24 to 123 microfilariae ( $\mathrm{mf}$ ) per mosquito (mosq). The average numbers of $\mathrm{mf} / \mathrm{mosq}$ were $4.8 \pm 4.3$ to $24.6 \pm 23.3$ (Tables I, II). Statistical analysis (Duncan Test) revealed a significant difference in the average number of $\mathrm{mf} / \mathrm{mosq}$ for PE and RO populations of $C x$. quinquefasciatus ( $24.6 \pm 23.3$; $4.8 \pm 4.3$, respectively). No significant differences were observed between the average number of $\mathrm{mf} /$ mosq in $C x$. quinquefasciatus from $\mathrm{PE}$ and $A e$. aegypti $(26.6 \pm 11.5)$ or between RO population and the other populations of $C x$. quinquefasciatus (Tables I, II). Calheiros et al. (1998) infected $C x$. quinquefasciatus with $W$. bancrofti and encountered three to 102 larvae (average $19.8 \pm 19.5$ ) in the midgut of $97 \%$ of mosquitoes dissected immediately after feeding on infected blood. Loftin et al. (1995) reported average levels of $\mathrm{mf} / \mathrm{mosq}$ of $34.2 \pm 6.3,29 \pm 6.1$ and $39.3 \pm 11$ in $C x$. quinquefasciatus, $C x$. tarsalis and Ae. vexans respectively, that fed on a dog infected with $D$. immitis. In our experiments all Ae. aegypti were found to be infected with an average $\mathrm{mf} / \mathrm{mosq}$ level of $26.6 \pm 11.5$ (Tables I, II).

We observed a rapid coagulation of midgut contents in female $C x$. quinquefasciatus which were dissected within $1 \mathrm{~h}$ of feeding. Here, the formation of crystals, a considerable reduction in the

\section{TABLE I}

Distribution of infected and infective mosquitoes, number of microfilariae ( $\mathrm{mf}$ ) ingested by female Culex quinquefasciatus of different origin and by Aedes aegypti, fed on a naturally infected $\operatorname{dog}$ $(\sim 6 \mathrm{mf} / 20 \mu \mathrm{l}$ of blood)

\begin{tabular}{|c|c|c|c|c|c|c|c|}
\hline \multirow[t]{2}{*}{$\begin{array}{l}\text { Mosquitoes } \\
\text { species/ } \\
\text { Origins }\end{array}$} & \multicolumn{2}{|c|}{$\begin{array}{c}\text { Total of } \\
\text { mosquitoes }\end{array}$} & \multicolumn{2}{|c|}{$\begin{array}{c}\text { Mosquitoes } \\
\text { examined } \\
1 \mathrm{~h} \text { after feeding }\end{array}$} & \multirow{2}{*}{$\begin{array}{l}\text { Mosquitoes } \\
\text { examined from the } \\
\text { 1st to 10th day } \\
\text { after feeding } a \\
\text { No. of } \\
\text { infected mosq./ } \\
\text { dissected } \\
(\%)\end{array}$} & \multicolumn{2}{|c|}{$\begin{array}{l}\text { Mosquitoes with } \mathrm{L}_{3} \\
\text { (infective larvae) } \\
\text { between the } 11 \text { th to } 15 \text { th } \\
\text { day after feeding } b\end{array}$} \\
\hline & $\begin{array}{l}\text { Engorged } \\
(\%)\end{array}$ & Dissected & $\begin{array}{c}\text { No. of } \\
\text { infected } \\
\text { mosq./dissec. } \\
(\%)\end{array}$ & $\begin{array}{c}\mathrm{mf} / \mathrm{mosq} \\
\text { dissected } \\
\mathrm{X} \pm \mathrm{S}\end{array}$ & & $\begin{array}{c}\overline{\mathrm{X}} \\
\mathrm{L}_{3} / \text { dissected } \\
\text { mosq. }\end{array}$ & $\begin{array}{c}\overline{\mathrm{X}} \\
\mathrm{L}_{3} / \text { infected } \\
\text { mosq. }\end{array}$ \\
\hline \multicolumn{8}{|c|}{ Cx. quinquefasciatus } \\
\hline Pernambuco & $\begin{array}{l}295 \\
(98)\end{array}$ & 172 & $\begin{array}{c}5 / 5 \\
(100)\end{array}$ & $24.6 \pm 23.3$ & $\begin{array}{c}4 / 17 \\
(23.5)\end{array}$ & 0.1 & 1.4 \\
\hline Rio de Janeiro & $\begin{array}{l}121 \\
(40)\end{array}$ & 90 & $\begin{array}{c}5 / 5 \\
(100)\end{array}$ & $8.6 \pm 4.5$ & $\begin{array}{c}6 / 16 \\
(37.5)\end{array}$ & $<0.1$ & 1 \\
\hline Rondônia & $\begin{array}{l}136 \\
(45)\end{array}$ & 111 & $\begin{array}{c}5 / 5 \\
(100)\end{array}$ & $4.8 \pm 4.3$ & $\begin{array}{l}12 / 19 \\
(63.2)\end{array}$ & 0.1 & 1.5 \\
\hline Maranhão & $\begin{array}{l}164 \\
(55)\end{array}$ & 142 & $\begin{array}{c}5 / 5 \\
(100)\end{array}$ & $9.8 \pm 8.9$ & $\begin{array}{c}6 / 14 \\
(42.8)\end{array}$ & 0.1 & 1.2 \\
\hline Santa Catarina & $\begin{array}{l}142 \\
(47)\end{array}$ & 107 & $\begin{array}{c}5 / 5 \\
(100)\end{array}$ & $6.8 \pm 6.6$ & $\begin{array}{c}6 / 22 \\
(27.3)\end{array}$ & $<0.1$ & 1.5 \\
\hline Ae. aegypti & $\begin{array}{l}170 \\
(57)\end{array}$ & 134 & $\begin{array}{c}5 / 5 \\
(100)\end{array}$ & $26.6 \pm 11.5$ & $\begin{array}{l}84 / 87 \\
(96.5)\end{array}$ & 4 & 4.1 \\
\hline
\end{tabular}

$a$ : larvae encountered solely in the Malpighian tubules; $b$ : total counts for $\mathrm{L}_{3}$ observed in the Malphigian tubules, head and mouth parts, in accordance with the scheme of Kartman (1953, 1954). 
movement of the microfilariae and the presence of dead or injured larvae were observed. Similar observations were reported by Nayar and Sauerman (1975) and Lowrie (1991), who suggested that the presence of crystals of oxyhemoglobin, resulting from the lysis of blood cells, was the principle factor responsible for the reduced larval activity and death of $D$. immitis following ingestion by $C x$. quinquefasciatus. In addition, Lowrie (1991) in a study with $C x$. quinquefasciatus found that $12 \%$ of the $\mathrm{mf}$ of $D$. immitis had been damaged by the action of the cibarial armature. In the present study, the rapid coagulation and formation of crystals was not observed in Ae. aegypti, instead the microfilariae were active and moving freely in the midgut soon after their ingestion.

Regarding the number of larvae encountered in female $C x$. quinquefasciatus at different sampling times, no significant differences were noted between females dissected $48 \mathrm{~h}$ post engorgement $\left(\chi_{\alpha 5}^{2}=2.15\right)$ and those sampled at intervals between three to seven days $\left(\chi^{2} \alpha 5=3.437\right)$ or between 11 to 15 days $\left(\chi_{\alpha 5}^{2}=2.956\right)$ (Table II). Similarly, differences were not observed between the mean larval development/mosquito for different test populations of $C x$. quinquefasciatus $\left(\chi^{2}{ }_{\alpha 5}\right.$ $=3.84$ ). During the 8th to 10th day post feeding, moribund female $C x$. quinquefasciatus were dissected but none were found to be infected (Table II). Macêdo et al. (1998) encountered averages of 6.9 and 8.4 larvae/mosquito in Ae. scapularis and Ae. aegypti fed using an apparatus containing blood infected with $D$. immitis (60 to $70 \mathrm{mf} / 20 \mu \mathrm{l})$. In our experiments the mean numbers of $\mathrm{mf} / \mathrm{mosq}$ recorded in Ae. aegypti were greater than those observed in $C x$. quinquefasciatus at all sampling times (Table II). More female Ae. aegypti maintained larvae in the Malpighian tubules than $C x$. quinquefasciatus, irrespective of the origin of the population ( 23.5 to $63.2 \%$ of infected mosquitoes) (Table I).

The data indicate that the infection during the first 48-h feeding period for $C x$. quinquefasciatus was not sufficient to induce an elevated level of mortality in those mosquitoes: MA $1.46 \%(2 / 137)$, PE $2.39 \%$ (4/167), SC $2.94 \%$ (3/102), RO 5.66\% $(6 / 106)$ and RJ 7.06\% (6/85). Significant differences were not noted $\left(\chi_{\alpha 5}^{2}=5.7\right)$ when we compared the mortality levels of different populations of $C x$. quinquefasciatus. However, populations of $C x$. quinquefasciatus and Ae. aegypti showed a marked difference. During this period the level of mortality observed for Ae. aegypti was elevated $(31 \%)$. These results are similar to those reported by Serrão (1998), i.e. 24.7 and $35.7 \%$ for females fed on blood with moderate microfilaraemia $(3,000$ to $5,000 \mathrm{mf} / \mathrm{ml}$ ). Although the female $C x$. quinquefasciatus from $\mathrm{PE}$ had ingested a significantly larger number of $\mathrm{mf}$ than had any other population, this did not result in a higher mortality rate in the two days following the infected blood meal. In the case of Ae. aegypti there was a correlation between the number of $\mathrm{mf}$ ingested and mortality rate. These data support the hypothesis that fewer live $\mathrm{mf}$ reach the Malpighian tubules in $C x$. quinquefasciatus than in Ae. aegypti, owing to

\section{TABLE II}

Number of Dirofilaria immitis larvae observed over a 15 day period in female Culex quinquefasciatus from different regions of Brazil and in Aedes aegypti, that fed on an infected dog ( 6 microfilariae/20 $\mu$ blood).

$$
\text { Average in parenthesis }
$$

\begin{tabular}{lcccccc}
\hline Mosquito species/ & \multicolumn{5}{c}{ No. of larvae encountered/No. of mosquitoes dissected } \\
\cline { 2 - 6 } Origin & $1 \mathrm{~h}$ & until $48 \mathrm{~h}$ & $3-7$ days & $8-10$ days & $11-15$ days & Total \\
\hline $\begin{array}{l}\text { Cx. quinquefasciatus } \\
\text { Pernambuco }\end{array}$ & $123 / 5$ & $24 / 4$ & $37 / 6$ & $0 / 7$ & $22 / 150$ & $206 / 172$ \\
& $(24.6)$ & $(6)$ & $(6.2)$ & $(0)$ & $(0.2)$ & $(1.2)$ \\
Rio de Janeiro & $43 / 5$ & $73 / 6$ & $47 / 5$ & $0 / 5$ & $2 / 69$ & $165 / 90$ \\
& $(8.6)$ & $(12.2)$ & $(9.4)$ & $(0)$ & $(<0.1)$ & $(1.8)$ \\
Rondônia & $24 / 5$ & $61 / 6$ & $37 / 10$ & $0 / 3$ & $8 / 87$ & $130 / 111$ \\
& $(4.8)$ & $(10.2)$ & $(3.7)$ & $(0)$ & $(0.1)$ & $(1.2)$ \\
Maranhão & $49 / 5$ & $15 / 2$ & $52 / 8$ & $0 / 4$ & $13 / 123$ & $129 / 142$ \\
& $(9.8)$ & $(7.5)$ & $(6.5)$ & $(0)$ & $(0.1)$ & $(0.9)$ \\
Santa Catarina & $34 / 5$ & $38 / 3$ & $26 / 10$ & $0 / 9$ & $3 / 80$ & $101 / 107$ \\
& $(6.8)$ & $(12.7)$ & $(2.6)$ & $(0)$ & $(<0.1)$ & $(0.9)$ \\
Ae. aegypti & $133 / 5$ & $1046 / 48$ & $486 / 38$ & $3 / 1$ & $221 / 42$ & $1889 / 134$ \\
& $(26.6)$ & $(21.8)$ & $(12.8)$ & $(3.0)$ & $(5.3)$ & $(14.1)$ \\
\hline
\end{tabular}


the barriers encountered in the digestive tract. These barriers may include the action of the cibarial armature, blockage by rapid coagulation of the ingested blood and the presence of crystals (Nayar \& Sauerman 1975, McGreevy et al 1978, Lowrie 1991, Loftin et al. 1995).

At the end of the 15-day post feeding period no significant difference in survival was observed among the test $C x$. quinquefasciatus populations $\left(\chi_{\alpha 5}^{2}=6.66\right)$, with a variation of between $50.8 \%$ to $75 \%$ (Table III). Levels of survival were greater than those reported by Brito et al. (1999), who only recorded a $30.6 \%$ survival in $C x$. quinquefasciatus from Alagoas (AL) infected with $D$. immitis. Moreover, our data differ from the values of 17 and 63\% survival reported by Lowrie (1991) using two different strains of $C x$. quinquefasciatus (Haiti and USA). Nevertheless, our values are similar to those observed by Calheiros et al. (1998) who evaluated the experimental infection of a Brazilian strain of $C x$. quinquefasciatus with $W$. bancrofti and reported $66 \%$ survival rate. A higher level of survival was observed for Brazilian populations of $C x$. quinquefasciatus in this study than Ae. aegypti (24.7\%) (Table III).

Third stage larvae were encountered in the Malpighian tubules only on day 11 in $C x$. quinquefasciatus from $\mathrm{PE}$ and MA and only on day 13 in specimens from RJ, RO and SC. Infec- tive larvae $\mathrm{L}_{3}$ were observed in the head and proboscis (H/p) from day 13 in $C x$. quinquefasciatus from MA and on day 14 in females from PE, RJ and SC. Females from RO were the only population that infective stage larvae were not observed in the $\mathrm{H} / \mathrm{p}$ within the 15 day observation period, despite the observation of live $\mathrm{L}_{3}\left(0.1 \mathrm{~L}_{3} / \mathrm{mosq}\right)$ in the Malpighian tubules (Table I). These findings are in agreement with studies on $C x$. quinquefasciatus from other locations (Kartman 1953, 1954, Villavaso \& Steelman 1970, Lowrie 1991, Loftin et al. 1995, Brito et al. 1999). In the case of Ae. aegypti, $\mathrm{L}_{3}$ were detected in the Malphigian tubules on day 11 and in the H/p on day 12 after feeding on the infected dog. In general terms, threefour times as many $\mathrm{L}_{3}$ were detected in Ae. aegypti than were found in $C x$. quinquefasciatus test populations ( 1 to $1.5 \mathrm{~L}_{3}$ /infected mosquito) (Table I).

The level of infection ranged from 12 to $20.7 \%$ in the populations of $C x$. quinquefasciatus (Table III), although no significant difference was observed $\left(\chi_{\alpha 5}^{2}=2.66\right)$. This level of infection was lower than that reported by Loftin et al. (1995), who observed the presence of $\mathrm{L}_{3}$ in $40.6 \%$ of infected $C x$. quinquefasciatus. The infection rate found in our study with Ae. aegypti was very high (96.3\%) (Table I), greatly surpassing the values of $27.6 \%$ for this species and $79.5 \%$ for Ae. scapularis noted by Macêdo et al. (1998).

TABLE III

Results of infection with Dirofilaria immitis in Culex quinquefasciatus from five distinct regions of Brazil and in Aedes aegypti after 15 days observation

\begin{tabular}{|c|c|c|c|c|c|}
\hline \multirow{2}{*}{$\begin{array}{l}\text { Mosquito species/ } \\
\text { Origin }\end{array}$} & \multicolumn{4}{|c|}{ Indexes $(\%)$} & \multirow{2}{*}{$\begin{array}{c}\text { Vector } \\
\text { efficiency } \\
\text { VE }(\%)\end{array}$} \\
\hline & Infection rates ${ }^{a}$ & Infectivity rate ${ }^{b}$ & $\begin{array}{l}\text { Intensity of } \\
\text { infection }^{c}\end{array}$ & Survival rate ${ }^{d}$ & \\
\hline \multicolumn{6}{|c|}{ CX. quinquefasciatus } \\
\hline Pernambuco & $\begin{array}{c}26 / 172 \\
(15.1 \%)\end{array}$ & $\begin{array}{c}13 / 150 \\
8.7\end{array}$ & $\begin{array}{c}10 / 13 \\
6.66\end{array}$ & $\begin{array}{c}150 / 295 \\
50.8\end{array}$ & 0.49 \\
\hline Rio de Janeiro & $\begin{array}{c}13 / 90 \\
(14.4 \%)\end{array}$ & $\begin{array}{c}2 / 69 \\
2.9\end{array}$ & $\begin{array}{c}1 / 2 \\
1.45\end{array}$ & $\begin{array}{c}69 / 121 \\
57\end{array}$ & 0.34 \\
\hline Rondônia & $\begin{array}{l}23 / 111 \\
(20.7 \%)\end{array}$ & $\begin{array}{c}4 / 87 \\
4.6\end{array}$ & $\begin{array}{c}0 / 4 \\
0\end{array}$ & $\begin{array}{c}87 / 136 \\
63.9\end{array}$ & 1.44 \\
\hline Maranhão & $\begin{array}{c}21 / 142 \\
(14.8 \%)\end{array}$ & $\begin{array}{c}9 / 123 \\
7.3\end{array}$ & $\begin{array}{c}4 / 9 \\
3.25\end{array}$ & $\begin{array}{c}123 / 164 \\
75\end{array}$ & 0.91 \\
\hline Santa Catarina & $\begin{array}{l}13 / 107 \\
(12 \%)\end{array}$ & $\begin{array}{l}2 / 80 \\
2.5\end{array}$ & $\begin{array}{c}1 / 2 \\
1.25\end{array}$ & $\begin{array}{c}80 / 142 \\
56.3\end{array}$ & 0.55 \\
\hline Ae. aegypti & $\begin{array}{l}129 / 134 \\
(96.3 \%)\end{array}$ & $\begin{array}{c}27 / 42 \\
64.3 \\
\end{array}$ & $\begin{array}{c}20 / 27 \\
47.6 \\
\end{array}$ & $\begin{array}{c}42 / 170 \\
24.7\end{array}$ & 15.31 \\
\hline
\end{tabular}

$a$ : number of mosquitoes infected/number of mosquitoes dissected; $b: \mathrm{L}_{3}$ in the head and proboscis $(\mathrm{H} / \mathrm{p})$ and Malpighian tubules/number surviving mosquitoes; $c$ : number of mosquitoes with $\mathrm{L}_{3}$ in the $(\mathrm{H} / \mathrm{p}) /$ number of mosquitoes with $\mathrm{L}_{3} ; d$ : number of surviving mosquitoes/number of engorged mosquitoes; VE (\%): $\mathrm{X}$ number of $\mathrm{L}_{3} \times 100 / \mathrm{X}$ number of $\mathrm{mf}$ ingested among dissected mosquitoes; in according to Kartman $(1953,1954)$, Ramachandan (1970) and Brito et al. (1997). 
The level of infectivity fluctuated (2.5 to 8.7\%) depending on the $C x$. quinquefasciatus population (Table III). The intensity of the infection [mosq with $L_{3}$ in the $H / p / m o s q$ with $L_{3}$ in any other location] evaluated on day 15 post feeding also varied in relation to population origin i.e. $6.7 \%$ in $\mathrm{PE}$ to $1.2 \%$ in SC, without including Cx. quinquefasciatus from $\mathrm{RO}$, since no $\mathrm{L}_{3}$ were encountered in the $\mathrm{H} / \mathrm{p}$ at the conclusion of the experiment. In the case of Ae. aegypti, the level of infection was $96.3 \%$ and the intensity of infection reached $47.6 \%$.

The vector efficiency (VE) was low ( 0.3 to $1.4 \%$ ) for different populations of $C x$. quinquefasciatus, with no significant differences between populations $\left(\chi_{\alpha 5}^{2}=1.79\right)$. These values were similar to those obtained by Kartman (1953) of $0.8 \%$ and by Lowrie (1991) who reported values of 0.3 to $1.6 \%$. In both studies $C x$. quinquefasciatus females were fed under conditions of microfilaraemia similar to those in our experiment. However, our values are slightly higher than that reported by Brito et al. (1999) (i.e. $\mathrm{VE}=0.0 \%$ ) and lower than that reported by Loftin et al. (1995), who determined a VE of $2.7 \%$ for the AL strain of $C x$. quinquefasciatus used in their study. In the case of Ae. aegypti, the VE in our study was $15.3 \%$, very similar to the value of $15.8 \%$ determined for this species by Brito et al. (1999).

Different Brazilian populations of $C X$. quinquefasciatus are capable of supporting the development of $D$. immitis until the infective stage, demonstrating that this species is susceptible to infection and has vector potential. Nevertheless, this susceptibility was limited for the specimens derived from five different population suggesting that $C x$. quinquefasciatus is of secondary importance in the transmission of $D$. immitis in Brazil. Coincidentally, $\mathrm{L}_{3}$ were not detected in the $\mathrm{H} / \mathrm{p}$ of $C x$. quinquefasciatus from $\mathrm{RO}$, the only location where $D$. immitis infection of this species of mosquito has yet to be reported. Possibly, this particular population may be more refractory than the other populations examined, with the infective cycle of the helminth being retarded in mosquitoes from RO. Irrespective of the population origin, the level of survival shown by $C x$. quinquefasciatus infected with $D$. immitis is higher than that seen for other vectors including $A e$. scapularis, Ae. aegypti, Ae. taeniorhynchus and Ae. fluviatilis (Nayar \& Sauerman 1975, Kasai \& Williams 1986, Lowrie 1991, Macêdo et al. 1998). This suggests that in areas where transmission is maintained by primary vectors of greater susceptibility and where the microfilaraemia is high among canine populations, $C x$. quinquefasciatus could play an important role in maintaining the transmission of $D$. immitis. This is, in part, because $C x$. quin- quefasciatus is present during the entire year (Labarthe et al. 1998a, Ahid \& Lourenço-deOliveira 1999) and the majority of the mosquitoes survive infection by $D$. immitis. In MA, where the incidence of biting by $C x$. quinquefasciatus in dog populations was much higher than in other localities such as in RJ, the vector capacity of $C x$. quinquefasciatus for $D$. immitis may be elevated (Labarthe et al. 1998a, Ahid \& Lourenço-deOliveira 1999). Finally, given that $C x$. quinquefasciatus is anthropophilic and occurs at high frequencies in areas where the prevalence of canine dirofilariasis is high, it seems possible that man will have an increased probability of becoming an occasional host for this parasite.

\section{ACKNOWLEDGMENTS}

To André Luiz da Silva, for his relevant collaboration; Mr Joaquim Ferreira Neto, Dr Fátima dos Santos and Dr Zulmira Medeiros for providing the mosquito samples from SC, RO and PB, respectively; Mr Elizado Costa and Dr Lucy Câmara of the FNS-Entomology/ São Luís, MA; Dr Eduardo Lago, for providing the dog for use in the experiment, to Dr Daniel Praseres (UEMA) for assistance during the animal infection, and to Prof. José Roberto Soares from the Department of Mathematics at UFMA for his assistance with statistical analyses.

\section{REFERENCES}

Ahid SMM, Lourenço-de-Oliveira R 1999. Mosquitos vetores potenciais da dirofilariose canina no Nordeste do Brasil. Rev Saú Públ 33: 560-565.

Ahid SMM, Lourenço-de-Oliveira R, Saraiva LQ 1999. Dirofilariose canina na Ilha de São Luís, Nordeste do Brasil: uma zoonose potencial. Cad Saú Públ 15: 405-412.

Alves LC, Cole EF, Athayde ACR 1993. Prevalência da filariose canina no bairro de Dois Irmãos, Recife, PE. Rev Brasil Parasitol Vet 2: 68.

Brito AC, Fontes G, Rocha EMM, Rocha, DAM, Regis L 1999. Development of Dirofilaria immitis (Leidy) in Aedes aegypti (L.) and Culex quinquefasciatus (Say) from Maceió, Alagoas, Brazil. Mem Inst Oswaldo Cruz 94: 575-576.

Brito AC, Williams P, Fontes G, Rocha EMM 1997. A comparison of two Brazilian populations of Culex quinquefasciatus (Say, 1823) from endemic and nonendemic areas to infection with Wuchereria bancrofti (Cobbold, 1877). Mem Inst Oswaldo Cruz 92: 33 36.

Calheiros CML, Fontes G, Williams P, Rocha EMM 1998. Experimental infection of Culex (Culex) quinquefasciatus and Aedes (Stegomyia) aegypti with Wuchereria bancrofti. Mem Inst Oswaldo Cruz 93: 855-860.

Christensen BN 1981. Observations on the immune responses of Aedes trivittatus against Dirofilaria immitis. Trans R Soc Trop Med Hyg 75: 439-443.

Christensen BN, Forton KF 1986. Hemocyte-mediated melanization of microfilariae in Aedes aegypti. $J$ Parasitol 72: 220-225. 
Christensen BN, Tracy JW 1989. Arthropod transmitted parasites: mechanisms of immune interaction. Am Zoology 29: 387-398.

Coluzzi M, Concetti A, Ascoli F 1982. Effect of cibarial armature of mosquitoes (Diptera:Culicidae) on blood-meal haemolysis. J Insect Physiol 28: 885888.

Janousek TE, Lowrie Jr RC 1989. Vector competency of Culex quinquefasciatus (Haitian strain) following infection with Wuchereria bancrofti. Trans $R$ Soc Trop Med Hyg 83: 679-680.

Kartman L 1953. Factors influencing infection of the mosquito with Dirofilaria immitis (Leidy, 1956). Exp Parasitol 2: 27-78.

Kartman L 1954. Suggestions concerning an index of experimental filaria infection in mosquitoes. Am J Trop Med Hyg 3: 329-337.

Kasai N, Mattos EA, Costa JO 1981. Dirofilaria immitis e Dipetalonema reconditum em cães de Vitória, Espírito Santo. Arq Esc Vet 33: 425-429.

Kasai N, Williams P 1986. Infecção experimental de Aedes fluviatilis (Lutz, 1904) por Dirofilaria immitis (Leidy, 1856). Rev Brasil Biol 46: 277-283.

Labarthe NV 1997. Dirofilariose canina: diagnóstico, prevenção e tratamento adulticida. Revisão de literatura. Clinica Vet 10: 10-16.

Labarthe NV, Serrão ML, Melo YF, Oliveira SJ, Lourenço-de-Oliveira R 1998a. Mosquito frequency and feeding habits in an enzootic canine dirofilariasis area in Niterói, State of Rio de Janeiro, Brazil. Mem Inst Oswaldo Cruz 93: 145-154.

Labarthe NV, Serrão ML, Melo YF, Oliveira SJ, Lourenço-de-Oliveira R 1998b. Natural potential vectors of Dirofilaria immitis (Leidy, 1856) in Itacoatiara, oceanic region of Niterói municipality, Rio de Janeiro, Brazil. Mem Inst Oswaldo Cruz 93: 425-432.

Lima DC, Melo YF, Serrão MLC, Labarthe NV 1996. Pesquisa da infecção por Dirofilaria immitis na cidade de Porto Velho, Rondônia. Anais do XVIII Cong. Brasil. Clin. Peq. Animais-Anclivepa, Pernambuco, p. 16.

Loftin KM, Byford RL, Loftin MJ, Craig ME 1995. Potential mosquito vectors of Dirofilaria immitis in Bernalillo country, New Mexico. J Am Mosq Control Assoc 11: 90-93.

Lourenço-de-Oliveira R, Deane LM 1995. Presumed Dirofilaria immitis infections in wild caught Aedes taeniorhynchus and Aedes scapularis in Rio de Janeiro, Brazil. Mem Inst Oswaldo Cruz 90: 387388.

Lowrie Jr RC 1991. Poor vector efficiency of Culex quinquefasciatus following infection with Dirofilaria immitis. J Amer Mosq Control Assoc 7: 30-36.

Lowrie Jr RC, Eberhard ML, Lammie PJ, Raccurt CP, Kartz SP, Duverseau YT 1989. Uptake and development of Wuchereria bancrofti in Culex quinquefasciatus fed on Haitian carriers with different microfilaria densities. Amer J Trop Med Hyg 41: 429-435.

Ludlam KW, Jachowski LA, Otto GF 1970. Potential vectors of Dirofilaria immitis. J Am Vet Med Ass 157: 1354-1359.

Macêdo FC, Labarthe N, Lourenço-de-Oliveira R 1998. Susceptibility of Ae. scapularis (Rondani, 1848) to Dirofilaria immitis (Leidy, 1856), an emerging zoonosis. Mem Inst Oswaldo Cruz 93: 435-437.

McGreevy PB, Bryan JH, Oothuman P, Kolstrup N 1978. The lethal effects of the cibarial and pharyngeal armatures of mosquitoes on microfilariae. Trans $R$ Soc Trop Med Hyg 72: 361-368.

Nayar JK, Sauerman DM 1975. Physiological basis of host, susceptibility of Florida mosquitoes to Dirofilaria immitis. J Insect Physiol 21: 1965-1975.

Ramachandran CP 1970. A Guide to Methods and Techniques in Filariasis Investigations, Filar Res Off Inst Med Res, Kuala Lumpur, 39 pp.

Robinson NB, Chavez CM, Conn JH 1977. Pulmonary dirofilariasis in man: A case report and review of the literature. J Thor Cardiov Surg 74: 403-408.

Serrão MLC 1998. Aedes aegypti (Linnaeus 1762) como Vetor de Dirofilaria immitis (Leidy 1856) e Ação da Ivermectina sobre Larvas do Nematóide neste Mosquito, Thesis, Instituto Oswaldo Cruz, Rio de Janeiro, $50 \mathrm{pp}$.

Talluri VM, Cancrini G 1994. An ultrastructural study on the early cellular response to Dirofilaria immitis (Nematoda) in the Malpighian tubules of Aedes aegypti (refractory strains). Parasite 1: 343-348.

Taylor AER 1960. The development of Dirofilaria immitis in the mosquito Aedes aegypti. J Helminthol 34: 27-38.

Villavaso EJ, Steelman CD 1970. Laboratory and field studies of the southern house mosquito, Culex pipiens quinquefasciatus Say, infected with the dog heartworm, Dirofilaria immitis (Leidy), in Louisiana. J Med Entomol 7: 471-476. 